https://doi.org/10.18485/iipe_cpti.2020.ch8

\title{
HEGEMONSKA STABILNOST U ERI OKRNJENOG TEHNOLOŠKOG SUVERENITETA
}

\begin{abstract}
Nenad STEKIĆ
Apstrakt: Savremena tehnološka dostignuća čine značajan faktor procesa globalizacije i njegov su nužan preduslov. Ona su jedno od sredstava kojim, u savremenom međunarodnom sistemu, države obezbeđuju globalno liderstvo kroz investiranje $\mathrm{u}$ razvoj telekomunikacionih i informacionih tehnologija. Ubrzan razvoj inovativnih tehnologija Narodne Republike Kine je sastavni deo njenog ekonomskog razvoja i značajan segment delovanja "ka spolja” kroz inicijativu „Pojas i put” i ostale regionalne sub-inicijative. Cilj ovog rada je da ispita da li uloga hegemona u sistemu međunarodnih odnosa, tradicionalno posmatrana kroz prizmu dominacije ostvarene sredstvima tvrde moći, može biti proširena i njegovim tehnološkim liderstvom. Autor sumira najznačajnije akademske pravce novijih istraživačkih studija koji se tiču strateških aspekata kineskog tehnološkog prisustva na primeru razvoja 5G. Centralni deo rada činiće analiza potencijalne tehnološke nezavisnosti država okupljenih u okviru inicijative "17+1", koja se odnosi na nabavku opreme i komercijalizaciju 5G tehnologije. Autor upućuje na probleme primene koncepta tehnološkog suvereniteta u uslovima globalizovanog multilateralizma, stavljajući akcenat na države formata "17+1" koje karakteriše relativno okrnjen tehnološki suverenitet. Nakon sumiranja aktuelnih akademskih napora za rekonceptualizovanjem tehnološkog suvereniteta, biće diskutovano o najznačajnijim uzrocima i faktorima koji utiču na delovanje tehnološki zavisnih država u međunarodnim odnosima. Autor zastupa tezu da tehnologija može predstavljati činilac koji će možda, po prvi put, u međunarodnom sistemu proizvesti benevolentnog hegemona.
\end{abstract}

Ključne reči: pojas i put, tehnološki suverenitet, Kina, Srbija, 17+1, Huawei, tehnologija, 5G mreže.

${ }^{1}$ Autor je istraživač-pripravnik, Institut za međunarodnu politiku i privredu, Beograd, e-mail: nenad.stekic@diplomacy.bg.ac.rs

Rad je nastao u okviru projekta „Srbija i izazovi u međunarodnim odnosima 2020. godine", koji finansira Ministarstvo prosvete, nauke i tehnološkog razvoja Republike Srbije, a realizuje Institut za međunarodnu politiku i privredu tokom 2020. godine. 


\section{Ima li mesta za novog hegemona na prostoru „17+1"?}

Narodna Republika Kina (NR Kina) je van svake sumnje postala dominantan ekonomski akter na globalnom planu. Mereno u apsolutnim iznosima, ova država još uvek nije prva u svetu po visini bruto društvenog proizvoda, ali je neosporna činjenica da ima najveći uticaj na globalne ekonomske tokove. ${ }^{2}$ Još od prvih decenija XX veka, tehnološki uticaj čini dominantno polje u kom velike sile nastoje da osiguraju svoj ekonomski položaj i učvrste svoju političku poziciju. Ostvarivanje tehnološkog uticaja obezbeđuje se kroz investicije $u$ razvoj pojedinih segmenata modernih telekomunikacionih i informacionih tehnologija. Upravo su savremena tehnološka dostignuća Narodne Republike Kine sastavni deo njenog ekonomskog razvoja, i predstavljaju nezaobilazan segment njenog delovanja ,"ka spolja” posredstvom inicijative „Pojas i put” (naročito kroz koncept "digitalnog Pojasa i puta" o čemu će reči biti kasnije) i ostale regionalne sub-inicijative. Literatura obiluje radovima koji tretiraju tehnološka dostignuća država kao element njihovog spoljnopolitičkog pozicioniranja. ${ }^{3}$ Nešto aktuelnija istraživanja postavljaju tehnološku razvijenost kao jednu od mogućih središnjih vrednosti u nadmetanju između velikih sila. ${ }^{4}$ Tehnološka suprematija država je godinama služila

${ }^{2}$ U 2018. godini, bruto društveni proizvod Kine iznosio je 13,6 biliona američkih dolara, dok je u istoj godini BDP Sjedinjenih Američkih Država iznosio 20,5 biliona. Procene Svetske banke su da će se BDP ove dve države izjednačiti do 2030. godine. Videti više u: GDP (current USD) China and United States, The World Bank, 2020, https:/ / data. worldbank.org/indicator/NY.GDP.MKTP.CD?locations $=\mathrm{CN}-\mathrm{US} \& v i e w=$ chart, 12/04/2020.

${ }^{3}$ Wanning Sun, "Mission impossible? Soft power, communication capacity, and the globalization of Chinese media", International Journal of Communication, Vol. 4, No. 1, 2009, pp. 54-72; John Krige, "Technological leadership and American soft power", in: Inderjeet Parmar and Michael Cox (eds), Soft Power and US Foreign Policy, Routledge, London, 2010, pp. 133-148; Richard Nelson, "US technological leadership: Where did it come from and where did it go?", Research Policy, Vol. 19, No. 2, 1990, pp. 117-132; James Lewis, Globalization and National Security: Maintaining US Technological Leadership and Economic Strength, Csis, Washington, 2004.

${ }^{4}$ Za više ovakvih radova videti u: Clélio Campolina Diniz, "The science and technology race and productive re-structuring: geoeconomic and geopolitical impacts", Revista Brasileira de Estudos Urbanos e Regionais, Vol. 21, No. 2, 2019, pp. 241-257. Aparna Basu et al., "China's rising leadership in science and technology: quantitative and qualitative indicators", Scientometrics, Vol. 117, No. 1, 2018, pp. 249-269; Tao Liu and Wing Thye Woo, "Understanding the US-China trade war", China Economic Journal, 
kao dodatni argument $\mathrm{u}$ razvoju postojećih teorijskih paradigmi, unapređujući njihov analitički potencijal u proučavanju međunarodnih odnosa. Mada razvijani u drugačijem istorijskom kontekstu, pojedini postulati su primenjivi na analiziranje savremenih međunarodnih odnosa. Zbog toga je glavni cilj ovog rada da ispita da li uloga hegemona u sistemu međunarodnih odnosa, tradicionalno posmatrana kroz prizmu dominacije ostvarene sredstvima tvrde moći, može biti proširena i njegovim tehnološkim liderstvom. Autor će sumirati najznačajnije novije istraživačke studije koje se tiču strateških aspekata kineskog tehnološkog prisustva u makroregionima duž inicijative „Pojas i put”, a naročito na prostoru država centralne i istočne Evrope (CIE). Ovo je izuzetno važno područje kineskog prisustva, imajući u vidu relativnu okrnjenost suvereniteta država koje se nalaze na ovom prostoru, ali i činjenicu da je to prostor koji NR Kini obezbeđuje prodor ka evropskom kontinentu.

Zarad potpunijeg teorijskog utemeljenja ovog rada, autor upućuje na teoriju hegemonske stabilnosti koja zagovara tezu o stabilnosti globalnog sistema (ili jednog od njegovih podsistema) na bazi postojanja jednog hegemona koji taj (pod)sistem održava stabilnim. Iako je dominantno primenjivana (i unapređivana) $\mathrm{u}$ teorijskom diskursu nauke $\mathrm{o}$ međunarodnim odnosima tokom prethodnih nekoliko decenija, često se prenebregava činjenica da je ova teorija primarno ekonomska. ${ }^{5}$ Njen utemeljivač, američki ekonomista Čarls Kindlberger (Charles P. Kindleberger) identifikuje hegemonsku stabilnost kao odliku sistema sa državom koja ima ulogu dominantnog hegemona. ${ }^{6}$ Navodeći preduslove koje velike sile treba da ispune zarad sticanja uloge hegemona, Kindlberger upućuje na postepenost u njihovoj ,izgradnji" ${ }^{7}$ Da bi se država pozicionirala kao hegemon sistema, neophodno je da ispuni tri preduslova: posedovanje

Vol. 11, No. 3, 2018, pp. 319-340; Gabriel Collins, “Brains vs. Grains: US Technological Leadership Faces a Stiff Challenge as Competition With China Heats Up", Issue Brief, June 26 2018, https:/ / scholarship.rice.edu/ bitstream/ handle/1911/102775/bi-brief062518-ces-techrace.pdf?sequence=1, 13/04/2020.

${ }^{5}$ Uprkos tome, zbog mnogobrojnih specifičnosti koji olakšavaju razumevanje odnosa velikih sila u međunarodnom sistemu, epistemološki dometi ove teorije prošireni su i na proučavanje međunarodnih odnosa.

${ }^{6}$ Charles Kindleberger, The World in Depression, 1929-1939, University of California Press, Oakland, 1973, pp. 197-98.

${ }^{7}$ Ibid., p. 199. 
snažne i rastuće ekonomije i razvijene tehnologije, posedovanje političkovojne, meke i tvrde moći, i spremnost i posvećenost da preuzme vodeću ulogu u međunarodnom sistemu. ${ }^{8}$ Ostvarivanje uloge hegemona, prema tvrdnjama Kindlbergera, zahteva i postojanje opšteg konsenzusa drugih država međunarodnog sistema koje tu vodeću državu percipiraju kao lidera.

Pored postojanja snažne i rastuće ekonomije, potrebno je i kumulativno ispunjenje uslova koji se odnose na razvijenu tehnologiju. $\mathrm{O}$ razvijenosti tehnologije treba suditi u kontekstu trenutnih dostignuća, pa ovu kategoriju karakteriše izrazita promenljivost, što je važno zarad dalje analize globalnog tehnološkog prisustva Kine. Dodatno, prema postulatima navedene teorije, država stiče status hegemona samo pod uslovom da ne ostane inertni subjekat. Shodno tome, država mora biti spremna da svoja preimućstva (vojna, ekonomska, politička i tehnološka) projektuje na ceo sistem, ili njegov veći deo. ${ }^{9}$ Prateći ovu liniju argumentacije, Kindlberger je osporio šanse za hegemonizam državama koje nisu otvorene prema međunarodnom sistemu u smislu konstantne interakcije sa drugim državama sistema. Varijanta ove teorije, koja se može primeniti na oblast međunarodne bezbednosti, prvi put je predstavljena u radu Majkla Veba (Michael Webb) i Stivena Krasnera (Stephen D. Krasner) 1989. godine, u kome pomenuti autori identifikuju postojanje diverzifikacije interesa država u vezi sa međunarodnom ekonomskom liberalizacijom i stabilnošću. ${ }^{10}$ Iako ovako organizovan sistem povećava apsolutni nivo blagostanja svih učesnika, neće sve države osetiti benefite. Kako ovi autori primećuju, ako obrazac takozvanih „relativnih dobitaka" ugrozi bezbednost moćnih država, međunarodna ekonomska liberalizacija postaje ograničena. ${ }^{11}$ Jedan od preduslova za dostizanje pozicije hegemona Kina je već zadovoljila, imajući u vidu da je zauzela mesto vodećeg svetskog tehnološkog aktera. ${ }^{12}$ Na kraju 2019. godine NR Kina je prestigla SAD u izvozu tehnoloških komponenti koje

\footnotetext{
${ }^{8}$ Ibid., p. 198.

${ }^{9}$ Ibid., p. 199.

${ }^{10}$ Michael Webb and Stephen D. Krasner, "Hegemonic stability theory: An empirical assessment", Review of International Studies, Vol. 15, No. 2, 1989, p. 184.

${ }^{11}$ Ibid., p. 185.

${ }^{12} \mathrm{Za}$ detaljnije diskusije $\mathrm{u}$ vezi sa tehnološkim liderstvom NR Kine u savremenom sistemu međunarodnih odnosa, videti više u: Richard Baum (ed.),China's four modernizations: The new technological revolution, Routledge, London, 2019; Kimberly
} 
rade na principu veštačke inteligencije. Njene kompanije Huavej (Huawei), Hikvision (Hikvision Digital Technology), Dahua (Dahua Corporation) i ZTE su u navedenom periodu ostvarile izvoz tehnoloških rešenja baziranih na alatima veštačke inteligencije u čak 75 zemalja (od čega su 36 deo Inicijative "Pojas i put"), dok su istovremeno kompanije iz SAD poput IMB-a, Palantir-a i Cisco-a, izvezle svoje proizvode u 32 države. ${ }^{13}$

Za razliku od teorije hegemonske stabilnosti, na kojoj se temelji jedan od mogućih modela analize svetskog sistema, za regionalni nivo analize (prostor "17+1") biće korišćen koncept tehnološke zavisnosti, odnosno tehnološkog suvereniteta. Stefan Kutur (Stephane Coutur) i Sofi Tupin (Sophie Toupin) navode da su države tehnološki suverene onda kada „samostalno mogu da razviju informacionu i tehnološku infrastrukturu i obezbede kontrolu njihovog korišćenja u skladu sa domaćim zakonima, potrebama i sopstvenim interesima" ${ }^{14}$ Zbog ovako restriktivno postavljenih kriterijuma pomenuti autori navode da postoji izuzetno malo država koje poseduju potpuni tehnološki suverenitet. ${ }^{15}$ Države formata ",17+1" karakteriše relativno okrnjen tehnološki suverenitet zbog nedovoljnih kapaciteta (ili njihovog odsustva) za sopstveni razvoj savremenih tehnologija. Imajući u vidu konstantni rast izvoza kineskih proizvoda na ovom prostoru, može se prihvatiti stav da projekcija tehnoloških dostignuća van sopstvene teritorije čini slučaj kineskog tehnološkog prisustva u državama , $17+1$ " naučno relevantnim problemom.

Nekada najznačajniji činilac nacionalne suverenosti, istovremeno $\mathrm{i}$ temelj potencijalnog narušavanja nacionalne bezbednosti - teritorija, $\mathrm{u}$ uslovima globalizovanog svetskog sistema praćenog postojanjem savremenih komunikacionih tehnologija, prestaje da ima značaj koji je imao pre. Raspravljajući o suverenitetu u eri digitalizovanog sveta, Renata Pinto (Renata Ávila Pinto) navodi da su informaciono-komunikacione

Houser, "The Innovation Winter Is Coming: How the US-China Trade War Endangers the World", San Diego Law Review, Vol. 57, No. 3, 2020, pp. 1-20.

${ }^{13}$ Tehnologije veštačke inteligencije su tokom 2019. godine bile u upotrebi u 176 zemalja sveta. Više videti u: Alex McFarland, "China Leading the Global Expansion and Exportation of AI Technology", Unite, 2020, https://www.unite.ai/china-leadingthe-global-expansion-and-exportation-of-ai-technology, 12/04/2020.

${ }^{14}$ Stephane Couture and Sophie Toupin, "What does the notion of "sovereignty" mean when referring to the digital?", New media E society, Vol. 21, No.1, 2019, p. 231.

${ }^{15}$ Ibid., p. 232. 
tehnologije, razvoj veštačke inteligencije, kao i sposobnost brzog raspoređivanja sistema i infrastrukture na tržištima u nastajanju koncentrisani u svega nekoliko zemalja, koje su sada u trci da postanu broj jedan. ${ }^{16}$ Ova autorka, s druge strane, spominje tzv. ,,oflajn" populacije koje nastanjuju države koje nemaju tehnoloških kapaciteta kao navedene pređašnje države, dodeljujući im status ,digitalnog feuda" ${ }^{17}$ Svako ko uspostavi kontrolu nad digitalnim feudima imaće ključnu ulogu u budućnosti, zaključuje Pinto. ${ }^{18}$ Proces digitalne feudalizacije nije imanentan samo nacionalnim državama već uključuje i pojedince, omogućujući tako raznovrsne uticaje na lokalne političke prilike, poput skandala koji se dogodio nakon izveštaja Kembridž Analitike (Cambridge Analytica) ${ }^{19}$ Pišući o uticajima (tada) novih tehnoloških dometa na ograničenja državne moći, Volter Vrajston (Walter B. Wriston) ukazuje na dramatičnost $u$ promenama međunarodnog sistema koja je uzrokovana masovnom upotrebom medija za audio i video prenos informacija do šire svetske javnosti. ${ }^{20}$ Ovaj autor ukazuje na izvestan stepen apsurda različitih srednjovekovnih stanovišta nacionalne suverenosti, koje bivaju relativizovane novim tehnološkim dostignućima. ${ }^{21}$ Zbog toga je istraživački napor $\mathrm{u}$ radu fokusiran na preispitivanje hegemonizma $\mathrm{u}$ eri tehnološkog suvereniteta kroz proširivanje tradicionalne uloge vojnopolitičkog hegemonstva na tehnološku dominaciju. U nastavku će biti predstavljena kineska tehnološka dostignuća u oblasti komunikacionih tehnologija (slučaj 5G), koja su dominantan adut NR Kine u sopstvenom globalnom tehnološkom pozicioniranju u predstojećoj deceniji, kao i transfer tehnologija na području država centralne i istočne Evrope.

\section{Globalni transfer kineskih tenhologija: slučaj 5G}

Upuštanje u specifikacije komunikacionih tehnologija ne predstavlja težnju ovog rada, niti on pledira da objasni 5G sa informatičko-

\footnotetext{
${ }^{16}$ Renata Ávila Pinto, “Digital Sovereignty or Digital Colonialism?", International Journal on Human Rights, Vol.15, No. 2, 2018, p. 16.

${ }^{17}$ Ibid., p. 17.

${ }^{18}$ Ibid., p. 17.

${ }^{19}$ Ibid., p. 19.

${ }^{20}$ Walter B. Wriston, "Technology and sovereignty", Foreign Affairs, Vol. 67, No. 2, 1988, p. 72.

${ }^{21}$ Ibid., p. 74.
} 
komunikacionog stanovišta. Umesto toga, komunikacione tehnologije $\mathrm{u}$ ovom radu uzete su kao studija slučaja na čijem primeru će biti proveren koncept tehnološkog suvereniteta i kapaciteta NR Kine da stekne ulogu hegemona $u$ međunarodnom sistemu. ${ }^{22} U$ nastavku će biti predstavljen pregled najznačajnijih specifičnosti ove tehnologije iz odabranih akademskih radova. Skraćenica za mobilne mreže „pete generacije” - 5G, osnovni je standard koji će činiti okosnicu revolucije mobilnog umrežavanja. Kao i prethodne, $4 \mathrm{G}$ i $3 \mathrm{G}$ tehnologije, 5G je tehnički standard koji povezuje više elektronskih uređaja u jedinstvenu mrežu. Ali, dok su prethodne tehnologije podržavale govornu, i komunikaciju podacima između telefona i drugih prenosivih uređaja, 5G je dizajniran za upravljanje vezama milijardi uređaja i bržim i pouzdanijim prenosom podataka. ${ }^{23}$ Stoga je najvažnija odlika $5 \mathrm{G}$ mreže upravo drastično uvećanje protoka i kapaciteta u odnosu na mreže prethodne generacije. U praktičnom smislu to ce značiti širenje infrastrukture, antena i povezanih uređaja od sistema video nadgledanja, do bespilotnih letelica, nosivih sredstava, povezanih automobila, frižidera, igraćih konzola i robota. ${ }^{24} 5 \mathrm{G}$ će postati tehnička osnova na kojoj će se odvijati svakodnevni život, ne na bazi upotrebe tehnologije, već kao alat koji omogućava aktivno učešće $u$ društvenim procesima. ${ }^{25}$ Najznačajnije kritike koje se upućuju novoj tehnologiji u akademskoj literaturi su one koje se tiču bezbednosti po ljude i životnu sredinu. One su uglavnom koncentrisane oko nedovoljne ispitanosti uticaja na zdravlje ljudske populacije. ${ }^{26} \mathrm{U}$

${ }^{22}$ Zbog toga, autor koristi 5G kao studiju slučaja ovog rada imajući u vidu njenu izrazitu aktuelnost $\mathrm{u}$ međunarodno-političkim previranjima i uticaj na konstelaciju odnosa velikih sila.

${ }^{23}$ John Hemmings, "Reconstructing Order: The Geopolitical Risks in China's Digital Silk Road", op. cit., p. 15.

${ }^{24}$ Ibid., p. 16.

${ }^{25}$ Ibid., p. 16.

${ }^{26}$ Za više detalja o inicijalnim postavkama, problemima i načinima ispitivanja uticaja 5G tehnologije na zdravlje ljudi, videti više u: Ijaz Ahmad et al., "Overview of 5G security challenges and solutions", IEEE Communications Standards Magazine, Vol. 2, No. 1, 2018 , pp. 36-43; Ijaz Ahmad et al., "5G security: Analysis of threats and solutions”, 2017 IEEE Conference on Standards for Communications and Networking (CSCN). IEEE, 2017, pp. 193199; Poorna Pravallika Sriram et al., "5G Security: Concepts and Challenges", in: Dushantha Jayakody and Kathiravan Srinivasan (eds), 5G Enabled Secure Wireless Networks, Springer, Cham, 2019. pp. 1-43; Arfaoui, Ghada, et al., "A security architecture for 5 G networks", IEEE Access, Vol. 6, No. 1, 2018, pp. 224-247. 
literaturi se kao karakteristike 5G navode da ona zahteva daleko više infrastrukture $\mathrm{u}$ odnosu na klasične bežične $4 \mathrm{G}$ tehnologije - naročito celije, specifične antene i nosive uređaje - jer koristi visoke radio frekvencije koje ne putuju do talasne dužine $4 \mathrm{G}$, što ima posledice na finansiranje i dizajn mrežne arhitekture. ${ }^{27}$ Pošto će se $5 \mathrm{G}$ koristiti za tehnološka čvorišta, poput pametnih gradova i luka, jasno je da ce uvođenje takve infrastrukture biti obimno i skupo. Osim toga, kao specifičnost ove tehnologije, navodi se i dominacija softverskih alata nad potpunim restrukturisanjem trenutne mrežne strukture. ${ }^{28} \mathrm{Zbog}$ oslanjanja na softversko vođenje, može se s pravom prihvatiti stav koji su izneli kineski autori Šan-ži Čen (Shan-zhi Chen) i Šao-li Kang (Shao-li Kang), da 5G predstavlja eru u kojoj je "sve međusobno isprepletano i povezano" ${ }^{29}$

U akademskoj literaturi još uvek ne postoji značajan broj naučnih radova koji 5G tretiraju kao slučaj na bazi kog se mogu istraživati odnosi velikih sila. Njihov deficit je uslovljen nedovoljnom istraženošću ove oblasti, kao i činjenicom da se radi o relativno novijem fenomenu koji se javlja u međunarodnim odnosima, a koji još uvek nije uspeo da zauzme istraživački fokus naučne zajednice. Kako još uvek ne postoji izdiferenciran skup istraživanja koja se oslanjaju na empirijsko proučavanje ovog fenomena, dominantnu sferu tehnološkog nadmetanja $\mathrm{u}$ vezi sa razvojem $5 \mathrm{G}$ tehnologije opisuju pregledne studije, različite forme izveštaja (objavljenih od strane vladinih agencija i nevladinih organizacija), kao i novinskih članaka. Pitanje razvoja 5G nije pitanje tehnološkog nadmetanja koje je karakterisalo klasične tržišne utakmice u sferi razvoja visokih tehnologija. Naprotiv, proces masovnijeg uvođenja 5G infrastrukture podrazumeva dve važne specifičnosti. Najpre, za razliku od većine tehnoloških rešenja, opremu koja emituje 5G ne karakteriše interoperabilnost. Primera radi, nije moguće infrastrukturno nadograditi opremu proizvedenu od strane evropskih kompanija opremom koju proizvodi Huavej. Ovakvo odsustvo interoperabilnosti u velikoj meri povećava jaz u kompeticiji na ovom planu. Druga značajna karakteristika jeste primetna razlika u ceni između kineske i evropske

\footnotetext{
${ }^{27}$ Ibid., p. 9.

${ }^{28}$ Shan-zhi Chen and Shao-li Kang, "A tutorial on 5G and the progress in China", Frontiers of Information Technology E Electronic Engineering, Vol. 19, No. 3, 2018, p. 319. ${ }^{29}$ Ibid., p. 320.
} 
opreme. Oprema koju proizvode kompanije ZTE i Huavej jeftinija je za čak $30-50 \%$ u odnosu na opremu proizvedenu od strane kompanije Erikson i Nokia. ${ }^{30}$ Srednjoročno, prednost jeftinije opreme značiće dominaciju kineskih visokosofisticiranih proizvoda na globalnom tržištu.

NR Kina je među prvim državama u svetu komercijalizovala upotrebu mreža 5G tehnologije na masovnom nivou, što se dogodilo 31. oktobra 2019. godine. Infrastrukturni nosioci projekta su bile tri državne kompanije - Telekom Kina (China Telecom), China Mobile, kao i China Unicorn. Pored navedenih, svakako najznačajniji kineski akter u oblasti razvoja komunikacionih tehnologija jeste kompanija Huavej (Huawei), koja se nalazi u državnom vlasništvu, mada potpuna vlasnička struktura nije transparentna. ${ }^{31}$ Prema pojedinim izvorima, čak 99\% Huaveja organizovano je po sistemu radničkog upravljanja koje se direktno nalazi u subordiniranom položaju u odnosu na Komunističku partiju. ${ }^{32}$ Huavej je jedan od vodećih aktera $5 \mathrm{G}$ tehnologije imajući u vidu da joj je cilj razvoj samostalnog programa 5G mreža do kraja 2020. godine, što prema pojedinim navodima predstavlja vremensku prednost od čak pet godina u odnosu na ostatak sveta. ${ }^{33}$ Kompanija je u toj meri značajna za globalne telekomunikacione tokove, da je sredinom 2019. godine, bila predmet blokade od strane Trampove administracije. ${ }^{34}$

Među aktuelnim promišljanjima o uticaju 5G izdvaja se stanovište Džona Hemingsa (John Hemmings), koji tvrdi da je 5G tehnologija samo jedan od medijuma na osnovu kog Kina nastoji da projektuje svoju

${ }^{30}$ Tarmo Virki and Angela Moon, "Exclusive: In push to replace Huawei, rural U.S. carriers are talking with Nokia and Ericsson", Reuters, June 25 2019, https:// www.reuters.com/article/us-huawei-tech-usa-nokia-ericssonexclus/exclusive-inpush-to-replace-huawei-rural-u-s-carriers-are-talking-with-nokia-and-ericssonid USKCN1TQ1VV, 12/04/2020.

${ }^{31}$ Iako je bilo nastojanja (dominantno dolazećih sa Zapada) da se istraži i utvrdi vlasništvo nad kompanijom Huavej, takvi pokušaji su ostali bez većih uspeha.

${ }^{32}$ Cain Burdeau, "Europe Becomes a Battleground over Huawei and 5G", Court House News, 2020, https:/ / www.courthousenews.com/europe-becomes-a-battlegroundover-huawei-and-5g, 17/04/2020.

${ }^{33}$ Paul Triolo and Kevin Allison, "The Geopolitics of 5G", Eurasia Group, 2018, https://www.eurasiagroup.net/live-post/the-geopolitics-of-5g, 17/4/2020.

${ }^{34}$ Daniel Drezner, "Economic Statecraft in the Age of Trump", The Washington Quarterly, Vol. 42, No. 3, 2019, p. 17. 
dominaciju u oblasti znatno složenijih tehničkih sistema upotrebom veštačke inteligencije. ${ }^{35}$ Kina nastoji da implementira analize kompleksnih serija podataka i mogućnosti koje pružaju alati veštačke inteligencije zarad izgradnje pametnih gradova i veće povezanosti uređaja. ${ }^{36}$ On tvrdi da će Inicijativa „Pojas i put” stvoriti ,globalni informatički autoput sa Kinom u svojoj srži". ${ }^{37}$ To je, nastavlja ovaj autor, način da ona uspostavi „novi poredak" koji će biti skrojen po preferencijama ove države najpre na regionalnom nivou, koji obuhvata geografski prostor „Pojasa i puta", a potom i na globalnom nivou, što je činjenica koju zapadne demokratije ne smeju zanemariti. ${ }^{38}$ Ovaj pristup odnosi se na stvaranje takozvane "zavodljive moći" (sticky power) koja prožima klastere - grupe koji se sastoje od pametnih gradova i luka, elektronske trgovine i promocije digitalnih valuta, kao i komunikacione i satelitske mreže. ${ }^{39}$ Navedeno stanovište je nastavak originalno razvijene ideje Džozefa Naja (Joseph Nye) o uticaju informacione revolucije na razvoj meke moći država. Informacije mogu često proizvesti ključ za sticanje moći, a prema stavu ovog autora, takav proces je istovremeno praćen masovnim pristupom informacijama od strane najvećeg dela svetske populacije. ${ }^{40}$

Kina je, na strategijskom nivou, uredila svoje aktivnosti u pogledu promocije 5G izvan svoje teritorije trinaestom po redu „Nacionalnom informatičkom strategijom za petogodišnji period", koja je objavljena 2016. godine. Sveopšta digitalizacija, prema navodima iz Strategije, predstavlja "nove produktivne snage i direktive razvoja" i postala je vodeća snaga kineskih inovacija. ${ }^{41}$ Nekoliko je strateških ciljeva predviđeno ovim petogodišnjim planom. Najpre, produbljeno učešće NR Kine $\mathrm{u}$ globalnom sistemu ekonomskog upravljanja predviđeno je kao najznačajniji strateški cilj u oblasti informacionih tehnologija. Pored toga,

${ }^{35}$ John Hemmings, "Reconstructing Order: The Geopolitical Risks in China's Digital Silk Road", Asia Policy, Vol. 27, No. 1, 2020, pp. 5-21.

${ }^{36}$ Ibid., p. 19.

${ }^{37}$ Ibid., p. 7.

${ }^{38}$ Ibid.

${ }^{39}$ Ibid.

${ }^{40}$ Joseph Nye, "The Information Revolution and Soft Power", Current History, Vol. 113, No. 7, 2014, p. 21.

41 "The National Thirteenth Five-Year Plan for National Informatization", Gazette of National Government of PR China, Beijing, 27 December 2016. 
ubrzanje razvoja digitalizacije, kako u Kini, tako i širom sveta, jeste još jedan od ciljeva koji Strategija proklamuje. ${ }^{42}$ Osim toga, značajan cilj jeste i izgradnja digitalnog tržišta koje će biti u stanju da zadovolji ogromne i narastajuće potrebe kineskih državljana. Na kraju, strategija predviđa ubrzanje razvoja digitalizacije kao elementa jačanja ,,kulturne meke moći NR Kine". ${ }^{43}$ Ovo se navodi kao cilj koji je ostvariv do kraja 2020. godine. $\mathrm{Na}$ kraju 2015. godine broj korisnika interneta u NR Kini je iznosio nešto manje od 700 miliona, što je ovu zemlju, prema tom indikatoru, svrstalo na prvo mesto u svetu. U Nacionalnoj informatičkoj strategiji Kine, navodi se, da su komunikacione mreže 3G i 4G instalirane i imaju domet na celoj teritoriji, dok 5G tehnologija zauzima „svetski ešalon" u ubrzavanju prenosa podataka. ${ }^{44}$ Saglasno tome, Strategija poziva na integraciju tri grupe navedenih mreža na širem planu zarad promocije integrisanosti konstrukcije radijskog i televizijskog signala, dok bežične satelitske veze bivaju unapređene. ${ }^{45}$ Najinteresantniji segment ove strategije čini deo koji tretira „Pojas i put” kao strateško polje na kome je potrebno širiti kineske komunikacione tehnologije. Navodeći značajan broj događaja koji su održani u povodu promocije digitalizacije i sveopšte informatizacije Azije, ova strategija zastupa stav, da je digitalna ekonomska saradnja postala "nova svetla tačka u saradnji na multilateralnom i bilateralnom nivou" ${ }^{46}$ Saglasno tome, grupa kineskih informatičkih kompanija je aktivno učestvovala $u$ instalaciji informacione infrastrukture $u$ državama duž „Pojasa i puta”. Ovo je od izuzetne važnosti, jer je ovim činom pružena državna podrška kompanijama da asertivnije prodru i u ovoj oblasti izvan granica NR Kine.

U akademskim raspravama o tzv. "digitalnom putu svile“, navode se dva ključna pitanja koja se tiču prirode strateške namere NR Kine u ovoj oblasti, kao i moguć uticaj ove inicijative na zapadne strateške ciljeve. Dok je prva faza ovakvog strateškog delanja okrenuta ka snažnom talasu investiranja od strane kineskih kompanija u državama duž „Pojasa i puta“, druga faza jeste nadmetanje sa zapadnim državama oko

\footnotetext{
42 Ibid., p. 4.

${ }^{43}$ Ibid., p. 4.

${ }^{44}$ Ibid., p. 5.

${ }^{45}$ Ibid., p. 6.

${ }^{46}$ Ibid., p. 7.
} 
preferiranih tehnoloških standarda zarad pobede $u$ informacionoj komunikacionoj tehnologiji nove generacije. ${ }^{47} \mathrm{Na}$ ovaj način $5 \mathrm{G}$ radi kao "građevinski blok" za druge tehnologije, koje predstavljaju inovativnost u prikupljanju, analizi i korišćenju podataka, uključujuci alate veštačke inteligencije, kvantno računanje i umrežavanje, finansijsku tehnologiju, industrijsku automatizaciju i druge nove tehnologije. ${ }^{48} \mathrm{U}$ svojoj knjizi posvećenoj analizi digitalne transformacije kineske ekonomije, Ju Hong (Yu Hong) tvrdi da je "digitalni put svile" upravo primer na kom Kina demonstrira napredak svojih tehnologija, uključujuci telekomunikacije, širokopojasne veze i ostale segmente savremenih komunikacionih tehnologija. ${ }^{49}$ Hong tvrdi da je komunikacijski sistem ukotvljen između dva paralelna ekonomska procesa: izvozno-prerađivački orijentisane ekonomije, vođene transnacionalnim kapitalom, i privrede koju reguliše država unutar sistema..$^{50}$

Kada je reč o komunikacionim tehnologijama, kinesko pozicioniranje na prostoru CIE u velikoj meri prati globalne tokove razvoja 5G mreže. Tokom 2020. godine, kompanija Huavej otvoriće sopstvenu fabriku u Francuskoj koja će proizvoditi opremu za instaliranje 5G mreža na evropskom kontinentu. ${ }^{51} \mathrm{U}$ junu 2019. godine, Kina je dala glavnim nacionalnim kompanijama ranije očekivane komercijalne dozvole za ubrzavanje uvođenja 5G. Ovim potezom je ublažen pritisak Vašingtona na Huavej, koji je uključivao pokušaje ubeđivanja svojih međunarodnih saveznika da izbegnu 5G usluge ove kompanije. Peking je od tada aktivirao mrežu $5 \mathrm{G} u$ više od 50 velikih gradova krajem 2019. godine, i planira da do kraja 2020. godine razmesti gotovo 700.000 baznih stanica $5 \mathrm{G}$ širom zemlje. ${ }^{52}$

${ }^{47}$ John Hemmings, "Reconstructing Order: The Geopolitical Risks in China's Digital Silk Road", op. cit., p. 9.

${ }^{48}$ Ibid., p. 9.

${ }^{49} \mathrm{Yu}$ Hong, Networking China: The Digital Transformation of the Chinese Economy, University of Illinois Press, Chicago, 2017.

${ }^{50}$ Ibid., p. 12.

${ }^{51}$ Mathieu Rosemain, "With West divided, Huawei plans first European 5G factory in France", Reuters, February 27 2020, https:/ /www.reuters.com/article/us-francehuawei/ with-west-divided-huawei-plans-first-european-5g-factory-in-franceidUSKCN20L246, 07/04/2020.

${ }^{52}$ Cheng Ting-Fang and Lauly Li, "Huawei tilts to telecom business as Beijing prepares big 5G push", Nikkei Asian Review, March 24 2020, https://asia.nikkei.com/ 
Potencijalno 5G tržište na prostoru „17+1”je ogromno. ${ }^{53}$ Nakon prvog samita u Varšavi 2012. godine, u tadašnjem formatu u kom je učestvovalo 16 država centralne i istočne Evrope, izraženo je nastojanje NR Kine da na ovom prostoru poveže Evropu i Aziju kroz različite vidove telekomunikacionih sredstava. Međutim, za osam godina postojanja ovog formata, prisustvo NR Kine se dominantno ogleda u investicijama u tešku industriju i velike infrastrukturne projekte. ${ }^{54}$ Sektor usluga, a naročito onih telekomunikacionih, tek je nedavno krenuo da se budi. Prema navodima baze podataka "China Global Investment Tracker", udeo kineskih investicija na prostoru 17+1, u sektoru tehnologija u periodu (2013-2019) iznosio je 940 miliona američkih dolara, što je svega 3,7\% od ukupne sume za isti period u kom je Kina investirala 25 milijardi dolara. ${ }^{55}$ Međutim, ove podatke treba uzeti sa rezervom imajući u vidu da sajt ne navodi tačne sektore tehnologije u koje Kina investira. S druge strane, iako većina država ovog prostora ima svoje nacionalne strategije digitalnog razvoja, NR Kina ni u jednoj još uvek nema formalno instaliranu $5 \mathrm{G}$ mrežu. Aktivnosti država koje učestvuju u formatu , 17+1" su u značajnoj meri usmerene ka donošenju strateških i legislativnih akata $u$ ovoj oblasti, i gotovo sve su na sličnom stupnju usvojenih akata. Pismo o namerama za razvoj 5G koridora potpisano je 2018. godine između Srbije, Grčke i Bugarske, a odnosilo se na saradnju u oblasti povezane i automatizovane vožnje, sa posebnim fokusom na bezbednost drumskog saobraćaja i efikasnosti upravljanja saobraćajem. Tri strane su definisale saobraćajni koridor kao objekat na kom će biti testirana implementacija "postojećih i budućih tehnologija” ${ }^{56}$ Hrvatska je svoju strategiju u ovoj oblasti usvojila 2016. godine, međutim u njoj se ne spominje

Spotlight/5G-networks/Huawei-tilts-to-telecom-business-as-Beijing-prepares-big5G-push, 07/04/2020.

${ }^{53}$ Posmatrano integralno, ovaj prostor sa približno 1,3 miliona kilometara kvadratnih svrstao bi se u 20 najvećih država na svetu, a nastanjuje ga nešto više od 130 miliona stanovnika.

${ }^{54}$ Više o kineskim investicijama na prostoru država "17+1“", videti u: Nenad Stekić, "Everlasting unsettled Sino-European relations: is " $16+1$ " initiative mutual benefit or point of divergence?" , The Review of International Affairs, Vol. 69, No. 1171, 2018, pp. 20-36.

55 "China Global Investment Tracker", The American Enterprise Institute, April 2020, https://www.aei.org/china-global-investment-tracker, 13/04/2020.

${ }_{1}^{56}$ "Pismo o namerama Republike Bugarske, Republike Grčke i Republike Srbije o saradnji u oblasti povezane i automatizovane vožnje“", Službeni Glasnik RS Međunarodni ugovori, broj 12/2018-327, Beograd, 2018. 
eksplicitno 5G tehnologija, već se naglašava značaj „infrastrukturnog razvoja tehnologija" koje omogućuju širokopojasni pristup mreži na brzini od $100 \mathrm{mbit} / \mathrm{s}^{57}$ Strategija proklamuje tri strateške grupe ciljeva koje se odnose na građane, privredu i na javnu upravu, a naročit akcenat stavljen je na neophodnost procene uticaja komunikacionih tehnologija na životnu sredinu. ${ }^{58}$ Češka Republika je usvojila „Nacionalni plan za razvoj mreža 5G" u oktobru 2016. godine. Plan stipuliše izgradnju mreža nove tehnologije koje će potpomoći sveukupni ekonomski razvoj. U Planu se navodi da će do kraja 2020. godine, svi građani imati mogućnost pristupa brzom internetu (bržem od $30 \mathrm{Mbit} / \mathrm{s}$ ) i da će najmanje polovina domaćinstava imati mogućnost da dobije internet vezu sa brzinom od $100 \mathrm{Mbit} / \mathrm{s}^{59}$ Mađarska, koja je inače proklamovala da će postati „,evropsko 5G čvorište" do 2021. godine, u svojoj komunikacionoj i medijskoj strategiji navodi četiri sveobuhvatna cilja: stimulisanje održivosti investicija u oblasti visokih tehnologija, modernizaciju upravljanja medijima, promociju interesa online korisnika i pretplatnika, i promovisanje izvrsnosti u upravljanju ovom oblašću..$^{60}$ Rumunija je u svojoj „5G Strategiji” iz 2018. godine predvidela da će do kraja 2020. cela država biti pokrivena komercijalnim uslugama nove tehnologije. ${ }^{61}$ Slična situacija je sa Grčkom čije je regulatorno telo COSMOTE već odabralo švedsku kompaniju Erikson (Ericsson) za licencirano postavljanje 5G infrastrukture, za šta je rok poslednji kvartal 2020. godine. ${ }^{62}$ Slovenija je odluku o dodeli 5G licenci stopirala u martu 2020. godine na neodređeni period zbog neutvrđenih potencijalno štetnih efekata ove tehnologije na ljude i životnu sredinu. ${ }^{63}$ Letonija i Litvanija su države koje

57 „Strategija razvoja širokopojasnog pristupa u Republici Hrvatskoj u razdoblju od 2016. do 2020. godine", Službeni List Republike Hrvatske, Zagreb, 2016.

58 Ibid., p. 6.

59 "National Plan for the Development of Next Generation Networks“, Ministry of Industry and Trade of the Czech Republic, Prague, March 2017.

60 "National Media and Infocommunications Authority Strategy 2018-2022“, NMHH, Budapest, 2018, p. 10.

61 "Strategia Pentru Romania", Ministry of Communications of the Republic of Romania, Bucharest, 2018, p. 13.

${ }^{62}$ COSMOTE Greece selects Ericsson 5G, Ericsson, March 24 2020, https:/ / www. ericsson. com/en/press-releases/2020/3/cosmote-greece-selects-ericsson-5g, 12/04/2020.

${ }^{63}$ Slovenia government delays decision on 5G licences, Telecompaper, March 5 2020, https:// www.telecompaper.com/news/slovenia-government-delays-decision-on5g-licences-1329243, 14/04/2020. 
za sada nemaju sektorske strategije kojima se tretira 5G tehnologija. U Republici Srbiji, krajem juna 2019. godine, kompanija Telenor je u Beogradu pustila u rad prvu baznu 5G stanicu, a do početka 2020. godine Srbija nije usvojila nijedan strateški dokument kojim bi regulisala oblast $5 \mathrm{G}$ mreža.

\section{Dileme koje se tiču tehnološkog suvereniteta država Inicijative „17+1”}

Nepotpun suverenitet $\mathrm{u}$ oblasti proizvodnje i korišćenja visokih tehnologija specifičan je za države centralne i istočne Evrope, pa se $u$ literaturi izdvajaju tri narativa koja korespondiraju mogućem ponašanju država ovog prostora. Prvi narativ naglašava Evropu kao civilizacijski aksiom koji upotpunjuje evropski identitet svake od 17 država. Za razliku od prvog, drugi narativ naglašava državni suverenitet, ističući nezavisnost svake države $\mathrm{u}$ odnosu na druge, i u odnosu na članstvo $\mathrm{u}$ Evropskoj uniji. Poslednji narativ u prvi plan postavlja prednost svake države u okviru formata "17+1", u pogledu njene "posebnosti” za privlačenje kineskih investicija. ${ }^{64}$ Tehnološko prisustvo Kine na ovom prostoru je $\mathrm{u}$ velikoj meri ograničeno sa nekoliko faktora. Najpre, $\mathrm{u}$ pojedinim državama, ne postoji podrška šire javnosti za uvođenje ovakvih tehnologija (slučaj Slovenije, Slovačke i Letonije). Čini se da nepoverenje javnosti u pogledu bezbednosnih aspekata 5G mreže, još uvek predstavlja značajnu kočnicu u njihovom instaliranju. Dodatno, čak 12 od 17 država ovog prostora su punopravne članice Evropske unije, pa je regulacija njihovih tržišta dominantno usmerena na zaštitu i promociju kompanija (i njihovih proizvoda) koje su locirane na području Unije, što bi potencijalno moglo isključiti jeftiniju i dostupniju kinesku opremu iz tržišne utakmice. Najzad, iako gotovo većina država formata ,17+1" ima nacionalne strategije $\mathrm{u}$ ovoj oblasti, na njihovoj implementaciji i operacionalizaciji predviđenih zadataka se u praksi malo odmaklo, a mali broj zemalja (pretežno države članice EU) u svojim nacionalnim zakonodavstvima na sistematičan način reguliše tržište u oblasti 5G. Svi pobrojani problemi su od velike važnosti za sagledavanje ograničenja koncepta tehnološkog suvereniteta. Na bazi uvida u trenutna dešavanja u vezi sa razvojem $5 \mathrm{G}$ mreže na prostoru država formata "17+1", mogu

${ }^{64}$ Emilian Kavalski, "China in Central and Eastern Europe: the unintended effects of identity narratives", Asia Europe Journal, Vol. 17, No. 1, 2019, p. 410. 
se identifikovati tri dileme koje će konstituisati dalju diskusiju o njihovom tehnološkom suverenitetu.

Prva dilema se odnosi na paradoks (ne)prihvatanja komercijalizacije novih tehnologija na svojoj teritoriji. Ukoliko država nema sposobnost da samostalno proizvede inovativna tehnološka dostignuća, težiće da učvrsti svoj tehnološki suverenitet kupovinom potrebne opreme od inostranog proizvođača. ${ }^{65}$ Ovde se može javiti paradoks, jer države pri ovakvom naporu mogu upasti u zamku narušavanja sopstvenog tehnološkog suvereniteta, zbog nepostojanja (ili neujednačenosti) pravnih akata kojima se regulišu nove tehnologije. Ovakvo stanje posledično onemogućava njihov monopol nad kontrolom u ovoj oblasti. ${ }^{66}$ Država koja nabavi opremu od kineskih proizvođača, na spoljašnjem planu može rizikovati narušavanje bilateralnih odnosa ili čak blaže sankcije (u slučaju članica Evropske unije) zbog nepoštovanja principa zajedničkog tržišta. Na unutrašnjem planu takođe se može suočiti sa izazovima koji mogu narušiti njen tehnološki suverenitet. Džozef Naj podseća, da masovni pristup informacijama unutar država vodi ka difuziji i opadanju moći nacionalnih vlada na račun nedržavnih aktera, dominantno velikih korporacija i ad hoc grupa. ${ }^{67}$ Dodatno, Naj navodi da okrnjenost tehnološkog suvereniteta koja se preliva na korporacije i neformalne grupe nikako ne znači kraj države, već samo difuziju određenih svojstava moći koje je ona prenela na potonje subjekte. ${ }^{68} \mathrm{Zbog}$ toga je važno postići srazmernost u kontroli komercijalizacije visokih tehnologija i očuvanja državnih monopola nad regulacijom njihove upotrebe.

Druga dilema tiče se donošenja konkretne odluke države u vezi sa isporučiocem $5 \mathrm{G}$ opreme. Kako trenutno stanje na tržištu karakteriše nesaobraznost opreme koja podržava ovu tehnologiju, države će morati da biraju između opreme proizvedene u Kini ili u nekoj zapadnoevropskoj državi. Uprkos nacionalnim zakonodavstvima, koja favorizuju kompanije

\footnotetext{
${ }^{65}$ Tao Liu and Woo Wing Thye, "Understanding the US-China trade war", China Economic Journal, Vol. 11, No. 3, 2018, p. 325.

${ }^{66}$ Ranije u tekstu je istaknuto da okrnjenost tehnološkog suvereniteta može biti uzrokovana neadekvatnom legislativom u oblasti visokih tehnologija na nacionalnom nivou.

${ }^{67}$ Joseph Nye, "The Information Revolution and Soft Power", op. cit., p. 23.

${ }^{68}$ Ibid., p. 22.
} 
sa prostora Evropske unije, izvesno je da će većina 5G opreme na prostoru centralne i istočne Evrope biti nabavljena od kineskih dobavljača, zbog evidentne razlike $\mathrm{u}$ ceni $\mathrm{u}$ odnosu na evropsku opremu. ${ }^{69}$ Dodatan podsticaj konkurentnosti kineske opreme pružaju kineske državne banke, koje dotiraju finansijsku pomoć u opsegu između 20 i 30 milijardi evra gigantskim kompanijama ZTE i Huavej, što potonjim omogućava bržu prodornost na nacionalna tržišta i prednost $u$ odnosu na evropske ili američke kompanije. ${ }^{70} \mathrm{U}$ ovom slučaju, države prostora ,"17+1" kao dominantni akteri na tržištu novih tehnologija, svojim strateškim i drugim normativnim aktima preciziraju opremu čija će instalacija biti moguća na njihovim teritorijama, a čime su posredno izvršile selekciju potencijalnih dobavljača. Kako nijedna država nije počela proceduru nabavke, nejasno je kakav će stav zauzeti Evropska unija po ovom pitanju.

Treća dilema $u$ vezi sa tehnološkim suverenitetom odnosi se na sistemski nivo analize. Na koji način će se ponašati Kina kao potencijalni hegemon sistema nakon što bude potvrđena njena dominacija $u$ sferi visokih tehnologija? Kako ekonomska ekspanzija Kine (još uvek) nije podržana značajnijom vojnom asertivnošću, odgovor na prethodno pitanje će u velikoj meri služiti kao osnova za teorijsko inoviranje koncepta tehnološke suverenosti. U slučaju "pobede” kineske nad zapadnom tehnologijom, biće značajno sagledati način na koji će Kina eksploatisati monopol u ovoj oblasti, kao i prirodu odnosa novog hegemona prema jedinicama sistema, koja nije izgrađena na temelju čiste tvrde moći. Identifikovane dileme razlažu koncept tehnološkog suvereniteta na tri međusobno komplementarne celine, od kojih svaka ima svojevrsni analitički potencijal. U svakom od tri slučaja, moguće je ustanoviti vezu između stabilnosti sistema bazirane na postojanju hegemona i okrenjenog suvereniteta $u$ oblasti visokih tehnologija.

${ }^{69}$ Kimberly Houser, "The Innovation Winter Is Coming: How the US-China Trade War Endangers the World", San Diego Law Review, Vol. 57, No. 3, 2020, p. 12.

70 Thomas S. Eder, Rebecca Arcesati and Jacob Mardell, "Networking the "Belt and Road" - The future is digital", Merics, August 28 2019, https:/ / www.merics.org/ en/bri-tracker/networking-the-belt-and-road, 07/04/2020. 


\section{Tehnološki razvoj kao zamajac benevolentnosti kineskog hegemonstva}

Polazna premisa autora ovog članka ukazala je na postojanje širenja tradicionalno posmatrane uloge hegemona, njegovim globalnim pozicioniranjem u oblasti novih komunikacionih tehnologija. Utvrđeno je da deficit tehnoloških dostignuća evropskih država u oblasti 5G, naročito na prostoru centralne Evrope i Balkana, može predstavljati vakuum čije ispunjenje bi etabliralo novog potencijalnog hegemona na ovom, i širem prostoru. Fokusiranje kineskog prisustva ka sektoru visokih tehnologija uklapa se u pretpostavke teorije prema kojoj je, za sticanje hegemonskog statusa $\mathrm{u}$ sistemu, potrebno da pored ispunjavanja preduslova hegemon mora da bude spreman da ih projektuje kroz tzv. "posvećenost sistemu" ${ }^{71}$ Ideje o hegemonskoj stabilnosti su nadživele nekoliko istorijskih epoha, a jedna od najsveobuhvatnijih debata o međunarodnim odnosima, vođena između neorealista i neoliberala („neo-neo“ debata) tokom poslednje decenije XX veka, bila je većim delom usmerena ka utvrđivanju uzroka (ne)stabilnosti unilateralnog sistema odnosa snaga. ${ }^{72}$ Specifičnosti savremenog sistema međunarodnih odnosa, koje se ogledaju u nesigurnom multipolarnom poretku, ponovo su aktuelizovali ideju o hegemonskoj stabilnosti, imajući u vidu poljuljanu poziciju SAD kao jedinog globalnog ekonomskog i vojnog lidera.

Nakon nešto više od 40 godina od „Velikog otvaranja”, Kina je izgradila specifičan vid odnosa prema međunarodnom sistemu koji se ne ogleda $u$ vojnoj asertivnosti, već u dominantno ekonomskom i kulturnom prisustvu. Takvo prisustvo Kine omogućeno je u nešto institucionalizovanijoj formi kroz Inicijativu „Pojas i put” od 2012. godine, otkada je zabeleženo intenziviranje kineskih investicionih aktivnosti i kulturne promocije na ogromnom prostoru Evroazije. Odnosi koje Kina gradi sa evropskim državama bazirani su na njenoj težnji da postane „novi svetski hegemon”, ili bar svetska ekonomska supersila. ${ }^{73}$ Međutim, u literaturi ne postoji

${ }^{71}$ Charles Kindleberger, “The World in Depression, 1929-1939”, op. cit., p. 34.

${ }^{72}$ Za opsežnu analizu dvaju teorijskih pravaca u objašnjavanju međunarodnih odnosa s kraja XX veka, videti više u: Joseph Nye, "Neorealism and neoliberalism", World Politics, Vol. 40, No. 2, 1988, pp. 235-251.

${ }^{73}$ Kerry Brown, The New Emperors: Power and the Princelings in China, Bloomsbury Publishing, London, 2014. 
konsenzus o „dobrim” namerama kineskog vođstva. Razlog „,tehnološke revolucije" koja se dešava u Kini treba tumačiti kao poruku upućenu SAD (ali i svetu), da kineska globalna dominacija neće biti usporena američkim suprotstavljanjem. ${ }^{74}$

Prisustvo Kine na prostoru država obuhvaćenih inicijativom ,17+1" korišćeno je kao studija slučaja $u$ ovom radu. Na bazi implementacije 5G tehnologije u ovim državama, pokazano je da koncept tehnološkog suvereniteta može predstavljati plodotvoran analitički alat u sagledavanju ponašanja tehnološki zavisnih država sa jedne, kao i mogućih opcija koje se nalaze pred novim hegemonom, sa druge strane. Kineski uticaj je $u$ poslednjih nekoliko godina, pored prostora centralne i istočne Evrope, percipiran kao pozitivan i u Africi i Latinskoj Americi, ali je negativan u SAD, većini zapadnoevropskih država, Indiji, Japanu i Južnoj Koreji. ${ }^{75}$ Ključna prednost Kine u oblasti razvoja informaciono-komunikacionih tehnologija na prostoru Evrope (i globalno) jeste masovnost u proizvodnji jeftine opreme koja se koristi kao infrastrukturna podrška 5G, pa se zato uspostavljanje "digitalnog puta svile”, kojim Kina nastoji da promoviše svoju tehnološku suprematiju, nalazi na vrhu kineske agende u bliskoj budućnosti. Način na koji će entiteti sa različitom zastupljenošću kapitala (državni, privatni, javnoprivatni ili neki drugi) sarađivati sa nacionalnim vladama duž „Pojasa i puta" jeste jedno od centralnih pitanja za buduća akademska proučavanja digitalnih, i aspekata koji se tiču razvoja savremenih komunikacionih tehnologija u državama koje su obuhvaćene ovom Inicijativom. ${ }^{76}$ Međutim, kako Kina $\mathrm{u}$ bliskoj istoriji nije bila dominantna supersila, teško je prognozirati da li će širenje njene dominacije na različitim poljima biti praćeno intenziviranjem vojnog prisustva. Zbog toga savremeni tehnološki razvoj jeste potencijalno „nova nepoznata” u jednačini hegemonskog nadmetanja, koje možda po prvi put neće proizvesti klasičnog vojno-političkog lidera u međunarodnom sistemu.

${ }^{74}$ John Hemmings, "The Hidden Dangers of China's Digital Silk Road", The National Interest, March 11 2020, https:/ / nationalinterest.org/feature/hidden-dangers-chinasdigital-silk-road-131887, 14/04/2020.

${ }^{75}$ Joseph Nye, "The Information Revolution and Soft Power", op. cit., p. 23.

${ }^{76}$ Hong Shen, "Building a Digital Silk Road? Situating the Internet in China's Belt and Road Initiative", International Journal of Communication, Vol. 12, No. 1, 2018, p. 695. 


\section{Bibliografija}

Ahmad, Ijaz, et al., "5G security: Analysis of threats and solutions”, 2017 IEEE Conference on Standards for Communications and Networking (CSCN). IEEE, 2017, pp. 193-199.

Ahmad, Ijaz, et al., "Overview of 5G security challenges and solutions", IEEE Communications Standards Magazine, Vol. 2, No. 1, 2018, pp. 36-43.

Arfaoui, Ghada, et al., "A security architecture for $5 \mathrm{G}$ networks", IEEE Access, Vol. 6, No. 1, 2018, pp. 224-247.

Ávila, Pinto Renata, "Digital Sovereignty or Digital Colonialism?", International Journal on Human Rights, Vol. 15, No. 2, 2018, pp. 15-27.

Basu, Aparna, et al., "China's rising leadership in science and technology: quantitative and qualitative indicators", Scientometrics, Vol. 117, No. 1, 2018, pp. 249-269.

Baum, Richard (ed.), China's four modernizations: The new technological revolution, Routledge, London, 2019.

Brown, Kerry, The New Emperors: Power and the Princelings in China, Bloomsbury Publishing, London, 2014.

Campolina, Diniz Clélio, "The science and technology race and productive re-structuring: geoeconomic and geopolitical impacts", Revista Brasileira de Estudos Urbanos e Regionais, Vol. 21, No. 2, 2019, pp. 241-257.

Chen, Shan-zhi, and Kang, Shao-li, "A tutorial on 5G and the progress in China", Frontiers of Information Technology \& Electronic Engineering, Vol. 19, No. 3, 2018, pp. 309-321.

Couture, Stephane, and Toupin, Sophie, "What does the notion of "sovereignty" mean when referring to the digital?", New media $\mathcal{E}$ society, Vol. 21, No.1, 2019, pp. 228-241.

Drezner, Daniel, "Economic Statecraft in the Age of Trump", The Washington Quarterly, Vol. 42, No. 3, 2019, pp. 7-24.

Gilpin, Robert, "The theory of hegemonic war", The Journal of Interdisciplinary History, Vol. 18, No. 4, 1988, pp. 591-613.

Gowa, Joanne, "Rational hegemons, excludable goods, and small groups: an epitaph for hegemonic stability theory?", World Politics, Vol. 41, No. 3, 1989, pp. 307-324. 
Hemmings, John, "Reconstructing Order: The Geopolitical Risks in China's Digital Silk Road", Asia Policy, Vol. 27, No. 1, 2020, pp. 5-21.

Hong, Yu, Networking China: The Digital Transformation of the Chinese Economy, University of Illinois Press, Chicago, 2017.

Houser, Kimberly, "The Innovation Winter Is Coming: How the USChina Trade War Endangers the World", San Diego Law Review, Vol. 57, No. 3, 2020, pp. 1-20.

Kavalski, Emilian, "China in Central and Eastern Europe: the unintended effects of identity narratives", Asia Europe Journal, Vol. 17, No. 1, 2019, pp. 403-419.

Kindleberger, Charles, The World in Depression, 1929-1939, University of California Press, Oakland, 1973.

Krige, John, "Technological leadership and American soft power", in: Inderjeet Parmar and Michael Cox (eds.), Soft Power and US Foreign Policy, Routledge, London, 2010, pp. 133-148.

Lewis, James, Globalization and National Security: Maintaining US Technological Leadership and Economic Strength, Csis, Washington, 2004.

Liu, Tao, and Thye, Woo Wing, "Understanding the US-China trade war", China Economic Journal, Vol. 11, No. 3, 2018, pp. 319-340.

Nelson, Richard, "US technological leadership: Where did it come from and where did it go?", Research Policy, Vol. 19, No. 2, 1990, pp. 117-132.

Nye, Joseph, "Neorealism and neoliberalism", World Politics, Vol. 40, No. 2, 1988, pp. 235-251.

Nye, Joseph, "The Information Revolution and Soft Power", Current History, Vol. 113, No. 7, 2014, pp. 19-32.

Pravallika, Sriram Poorna, et al., "5G Security: Concepts and Challenges”, in: Dushantha Jayakody and Kathiravan Srinivasan (eds), 5G Enabled Secure Wireless Networks, Springer, Cham, 2019. pp. 1-43.

Shen, Hong, "Building a Digital Silk Road? Situating the Internet in China's Belt and Road Initiative," International Journal of Communication, Vol. 12, No. 1, 2018, pp. 683-701.

Stekić, Nenad, „Everlasting unsettled Sino-European relations: is "16+1" initiative mutual benefit or point of divergence?", The Review of International Affairs, Vol. 69, No. 1171, 2018, pp. 20-36. 
Sun, Wanning, "Mission impossible? Soft power, communication capacity, and the globalization of Chinese media", International Journal of Communication, Vol. 4, No. 1, 2009, pp. 54-72.

Webb, Michael, and Krasner, Stephen D., "Hegemonic stability theory: An empirical assessment", Review of International Studies, Vol. 15, No. 2, 1989, pp. 183-198.

Wriston, Walter B., “Technology and sovereignty”, Foreign Affairs, Vol. 67, No. 2, 1988, pp. 63-75.

\section{Dokumenti:}

"Pismo o namerama Republike Bugarske, Republike Grčke i Republike Srbije o saradnji u oblasti povezane i automatizovane vožnje", Službeni Glasnik RS - Međunarodni ugovori, broj 12/2018-327, Beograd, 2018.

National Plan for the Development of Next Generation Networks, Ministry of Industry and Trade of the Czech Republic, Prague, March 2017.

National Media and Infocommunications Authority Strategy 2018-2022, NMHH, Budapest, 2018.

"Strategia Pentru Romania", Ministry of Communications of the Republic of Romania, Bucharest, 2018.

"Strategija razvoja širokopojasnog pristupa u Republici Hrvatskoj u razdoblju od 2016. do 2020. godine", Službeni List Republike Hrvatske, Zagreb, 2016.

"The National Thirteenth Five-Year Plan for National Informatization", Gazette of National Government of PR China, Beijing, 27 December 2016.

Internet izvori:

Alex, McFarland, "China Leading the Global Expansion and Exportation of AI Technology", Unite, 2020, https://www.unite.ai/china-leadingthe-global-expansion-and-exportation-of-ai-technology, 12/04/2020.

Burdeau, Cain, "Europe Becomes a Battleground Over Huawei and 5G", Court House News, 2020, https:/ / www.courthousenews.com/europebecomes-a-battleground-over-huawei-and-5g, 17/04/2020. 
"China Global Investment Tracker", The American Enterprise Institute, April 2020, https://www.aei.org/china-global-investment-tracker, 13/04/2020.

Collins, Gabriel, “Brains vs. Grains: US Technological Leadership Faces a Stiff Challenge as Competition With China Heats Up", Issue Brief, June 26 2018, https:/ / scholarship.rice.edu/bitstream/handle/ 1911/102775/bi-brief-062518-ces-techrace.pdf? sequence=1, 13/04/2020.

COSMOTE Greece selects Ericsson 5G, Ericsson, March 24 2020, https:// www.ericsson.com/en/ press-releases/2020/3/cosmotegreece-selects-ericsson-5g, 12/04/2020.

Eder, Thomas S., Arcesati, Rebecca and Mardell, Jacob, "Networking the "Belt and Road" - The future is digital", Merics, August 28 2019, https://www.merics.org/en/bri-tracker/networking-the-belt-androad, 07/04/2020.

GDP (current USD) China and United States, The World Bank, 2020, https://data.worldbank.org/indicator/NY.GDP.MKTP.CD?location $\mathrm{s}=\mathrm{CN}-U S \&$ view $=$ chart, $12 / 04 / 2020$.

Hemmings, John, "The Hidden Dangers of China's Digital Silk Road", The National Interest, March 11 2020, https:/ / nationalinterest.org/ feature/hidden-dangers-chinas-digital-silk-road-131887, 14/04/2020.

Rosemain, Mathieu, "With West divided, Huawei plans first European 5G factory in France", Reuters, February 27 2020, https://www. reuters.com/article/us-france-huawei/with-west-divided-huaweiplans-first-european-5g-factory-in-france-idUSKCN20L246, 07/04/2020.

Slovenia government delays decision on $5 \mathrm{G}$ licences, Telecompaper, March 5 2020, https:/ / www.telecompaper.com/news/slovenia-government -delays-decision-on-5g-licences - 1329243, 14/04/2020.

Ting-Fang, Cheng, and Li, Lauly, "Huawei tilts to telecom business as Beijing prepares big 5G push", Nikkei Asian Review, March 24 2020, https:/ / asia.nikkei.com/Spotlight/5G-networks/Huawei-tilts-totelecom-business-as-Beijing-prepares-big-5G-push, 07/04/2020.

Triolo, Paul and Allison, Kevin, "The Geopolitics of 5G", Eurasia Group, 2018, https:/ / www.eurasiagroup.net/live-post/the-geopolitics-of-5g, $17 / 4 / 2020$. 
Virki, Tarmo, and Moon, Angela, "Exclusive: In push to replace Huawei, rural U.S. carriers are talking with Nokia and Ericsson", Reuters, June 25 2019, https://www.reuters.com/article/us-huawei-tech-usanokia-ericssonexclus/exclusive-in-push-to-replace-huawei-rural-u-scarriers-are-talking-with-nokia-and-ericssonidUSKCN1TQ1VV, 12/04/2020.

\section{Nenad STEKIĆ \\ HEGEMONIC STABILITY IN AN ERA OF THE TRUNCATED TECHNOLOGICAL SOVEREIGNTY}

Abstract: Contemporary technological advances posit a significant factor and a prerequisite for the globalization process. They are one of the means by which, in a modern international system, countries provide global leadership through investment in telecommunications and information technologies development, which is an important instrument for achieving global political and economic dominance. It is precisely the modern technological achievements of the People's Republic of China that are an integral part of its economic development and a significant segment of "grand opening" through the Belt and Road Initiative and other regional sub-initiatives. This paper aims to examine whether the role of the hegemon in the system of international relations, traditionally perceived through the prism of dominance achieved using hard power, can be extended by its technological leadership. The author summarizes the most important academic directions of recent research studies concerning the strategic aspects of the Chinese technological presence on the example of $5 \mathrm{G}$ development. The central part of the paper will be the analysis of the potential technological independence of the countries gathered within the initiative " $17+1$ ", which refers to the procurement of equipment and commercialization of $5 \mathrm{G}$ technology. The author examines how the concept of technological sovereignty can be applied in the context of globalized multilateralism. Therefore, emphasis will be placed on the " $17+1$ " countries, characterized by relatively impaired technological sovereignty. After summarizing the current academic efforts to reconceptualize technological sovereignty, the most significant causes and factors that influence the strategic functioning of technologically dependent states in international relations will be discussed. The author argues that technology could be a factor that may, for the first time in the international system, produce a benevolence in hegemonic stability.

Key words: Belt \& Road, technological sovereignty, China, Serbia, initiative "17+1", Huawei, technology, 5G. 